\title{
KAJIAN KRIMINOLOGI TERHADAP PENELANTARAN ANAK SEBAGAI JENIS KEKERASAN DALAM RUMAH TANGGA
}

\author{
Oleh \\ Erinda Dhayana Putri Pertiwi, Safik Faozi
}

\begin{abstract}
ABSTRAK
Kekerasan dalam rumah tangga (KDRT) atau biasa disebut kekerasan domestik (domestic violence) merupakan suatu masalah yang sangat khas karena kekerasan dalam rumah tangga terjadi pada semua lapisan masyarakat. Sebagian besar korban kekerasan dalam rumah tangga khususnya penelantaran rumah tangga ini adalah anak. Kedudukan anak dalam rumah tangga lebih lemah, dan lebih rendah dari pada orang dewasa dan masih bergantung pada orang-orang dewasa di sekitarnya. Penelantaran anak merupakan bagian dari bentuk kekerasan terhadap anak, karena ia masuk kedalam kekerasan secara sosial (social abuse), Kekerasan yag bersifat psikis dan sosial (struktural) juga membawa dampak buruk dan permanen terhadap anak.

Berdasarkan uraian diatas, perumusan masalah dalam penulisan skripsi ini yang pertama adalah faktor-faktor apa saja yang menyebabkan terjadinya penelantaran terhadap anak didalam rumah tangga, kedua adalah bagaimana kajian kriminologi terhadap penelantaran anak sebagai jenis kekerasan dalam rumah tangga. Penelitian ini menggunakan metode pendekatan yuridis sosiologis. Untuk mendekati permasalahan dalam penelitian ini penulis menggunakan spesifikasi penelitian secara deskriptif analitis. Analisis ini yang dipergunakan dalam penulisan skripsi ini adalah kualitatif.

Berdasarkan hasil penelitian menunjukkan bahwa faktor-faktor yang menyebabkan terjadinya penelantaran terhadap anak didalam rumah tangga dapat dijelaskan menggunakan teori kriminologi meliputi teori differential association dan teori sosio-kultural (sosiologi kriminal), adapula faktor-faktor lain yang berkaitan dengan penelantaran terhadap anak, antara lain: faktor perceraian orang tua, faktor kemiskinan, faktor lingkungan dan faktor pendidikan. Kajian Kriminologi Terhadap Pelaku Penelantaran Anak dapat dijelaskan dengan teori kriminologi yaitu differential association terkait dengan perilaku kejahatan yang dipelajari karena faktor eksternal dan yang meliputi teknik dan motifnya. Kajian Penelantaran Anak Sebagai Jenis Kekerasan Dalam Rumah Tangga yaitu berupa penelantaran anak yang dilakukan oleh orang tuanya temasuk dalam jenis kekerasan yang terjadi dalam lingkup rumah tangga yaitu penelentaran dalam rumah tangga yang sesuai menurut Undang-Undang Nomor 23 Tahun 2004 tentang Penghapusan Kekerasan Dalam Rumah Tangga pada pasal 9 ayat 1.
\end{abstract}


Kata kunci : Kajian kriminologi, Penelantaran Anak, KDRT.

\section{LATAR BELAKANG}

Keutuhan dan kerukunan rumah tangga yang bahagia, aman, dan damai merupakan dambaan setiap orang dalam berkeluarga. Untuk mewujudkan keutuhan dan kerukunan tersebut sangat tergantung pada setiap orang dalam lingkup rumah tangga, terutama keharmonisan setiap anggota keluarga dalam rumah tangga tersebut.

Didalam berumah tangga, ketegangan maupun konflik merupakan hal yang biasa. Perselisihan pendapat, perdebatan, pertengkaran, atau bahkan memaki merupakan hal yang umum terjadi. Akan tetapi, apabila sampai pada hal yang menyakitkan apakah fisik maupun mental keadaan ini sudah menjadi persoalan lain. Kekerasan dalam rumah tangga (KDRT) atau biasa disebut kekerasan domestik (domestic violence) merupakan suatu masalah yang sangat khas karena kekerasan dalam rumah tangga terjadi pada semua lapisan masyarakat mulai dari masyarakat berstatus sosial rendah sampai masyarakat berstatus sosial tinggi. Sebagian besar korban KDRT adalah perempuan, apakah istri atau anak perempuan dan pelakunya biasanya adalah suami (walaupun ada juga korban justru sebaliknya) atau orang- orang yang tersubordinasi di dalam rumah tangga itu.

Perkembangan dewasa ini menunjukkan bahwa tindak kekerasan dalam rumah tangga juga beragam bentuknya, seperti: kekerasan secara fisik, psikis, seksual dan penelantaran rumah tangga. Sebagian besar korban dalam penelantaran rumah tangga ini adalah anak. Kedudukan anak dalam rumah tangga sebenarnya dalam posisi lebih lemah, lebih rendah karena secara fisik, mereka memang lebih lemah dari pada orang dewasa dan masih bergantung pada orang-orang dewasa di sekitarnya. Anak adalah amanah sekaligus karunia Tuhan Yang Maha Esa, yang senantiasa harus kita jaga karena dalam dirinya melekat harkat, martabat, dan hak-hak sebagai manusia yang harus dijunjung tinggi.

Berdasarkan uraian pada latar belakang diatas untuk mengetahui, memahami dan mengkaji mengenai penelantaran terhadap anak yang dilakukan oleh orang tuanya, maka peneliti tertarik untuk mengangkat dan menganalisis permasalahan dalam bentuk Skripsi dengan judul : "KAJIAN KRIMINOLOGI TERHADAP PENELANTARAN ANAK SEBAGAI JENIS KEKERASAN DALAM RUMAH TANGGA." 
RUMUSAN MASALAH

1. Apa saja faktor - faktor yang menyebabkan terjadinya penelantaran terhadap anak didalam rumah tangga?

2. Bagaimana kajian kriminologi terhadap penelantaran anak didalam rumah tangga?

\section{TUJUAN DAN MANFAAT PENELITIAN}

Tujuan Penelitian ini adalah :

a. Untuk menjelaskan faktor faktor yang menyebabkan terjadinya penelantaran terhadap anak didalam rumah tangga.

b. Untuk menjelaskan kajian kriminologi terhadap penelantaran anak didalam rumah tangga.

Adapun kegunaan dari penelitian ini adalah :

1. Manfaat Praktis

a. Lembaga Pemerintahan

b. Masyarakat

2. Manfaat Teoritis

Hasil penelitian ini diharapkan dapat menambah dan mengembangkan wawasan dan pengetahuan dalam ilmu hukum pada umumnya, khususnya mengenai kajian kriminologi terhadap penelantaran anak sebagai jenis kekerasan didalam rumah tangga.

\section{METODE PENELITIAN}

Metode pendekatan yang digunakan oleh penulis dalam penyusunan skripsi ini adalah metode pendekatan yuridis sosiologis yaitu metode yang memaparkan suatu pernyataan yang ada dilapangan berdasarkan asas-asas hukum, kaidah-kaidah hukum, atau perundangan-perundangan yang berlaku dan ada kaitannya dengan permasalahan yang dikaji.

\section{HASIL PENELITIAN DAN PEMBAHASAN}

\section{Faktor - faktor yang Menyebabkan Terjadinya Penelantaran Terhadap Anak didalam Rumah Tangga}

Penelantaran anak merupakan bagian dari bentuk kekerasan terhadap anak, karena ia masuk kedalam kekerasan secara sosial (social abuse), kekerasan terhadap anak seringkali diidentikan dengan kekerasan kasat mata, seperti kekerasan fisikal dan seksual. Padahal kekerasan yag bersifat psikis dan sosial (struktural) juga membawa dampak buruk dan permanen terhadap anak. Seorang anak dikatakan terlantar bukan karena ia sudah tidak memiliki salah satu orang tua atau keduanya, pengertian anak terlantar terdapat dalam Pasal 1 angka 6 UndangUndang Nomor. 35 Tahun 2014 perubahan atas Undang-Undang Nomor. 23 Tahun 2002 Tentang Perlindungan Anak yang menyebutkan bahwa:

“Anak terlantar adalah anak anak yang karena suatu sebab tidak terpenuhi kebutuhan dasarnya 
dengan wajar, baik rohani, jasmani, maupun sosial.”

Dalam penelitian ini diambil data dari para orang tua yang telah melakukan penelantaran terhadap anak. Dan dari data yang didapat, adanya tindakan penelantaran anak yang dilakukan oleh orang tua anak merupakan suatu perbuatan yang dikategorikan sebagai perbuatan tindak pidana dalam peraturan perundang-undangan yang mengatur tentang perlindungan anak yaitu Undang-Undang No.23 Tahun 2002 tentang Perlindungan Anak pada pasal 76 huruf a dan b dan Pasal 77 huruf b. Penelantaran terhadap anak yang dilakukan oleh orang tuanya dapat berupa penelantaran secara fisik, penelantaran pendidikan, penelantaran fasilitas medis, penelantaran secara emosi (kasih sayang) kepada anak yang menjadi korban penelantaran.

Berdasarkan wawancara dengan orang tua yang menelantarkan anaknya "Yaa mbak, saya memang sering menyuruh anak saya untuk ngamen dijalanan, tapi yaa mau gimana lagi karena terpaksa oleh keadaan dan hasil yang didapat juga lumayan, bisa bantu sedikit untuk keperluan sehari-hari.”

Hasil wawancara dengan orang tua anak yang lain "Kalau menurut saya, itu bukan suatu tindak kekerasan karena saya sebagai orang tua memang belum mampu memenuhi kebutuhan sehari-hari dan menyekolahkan dia (anak).”
Hal seperti penelantaran anak ini sudah sering dilakukan oleh orang tua yang kurang mampu secara ekonomi dan hal lainnya, karena para pihak orang tua mendapatkan keuntungan dari melakukan tindakan penelantaran anak tersebut. Berdasarkan hasil penelitian diatas, penelantaran anak termasuk tindak kejahatan sesuai dengan teori kriminologi yaitu teori differential association dan teori kejahatan dari faktor sosio-kultural (sosiologi kriminal).

a. Berdasarkan Faktor Differential Association

Teori Differential Association ini diajukan oleh E. Sutherland. Teori ini berdasarkan pada proses belajar., yaitu perilaku kejahatan adalah perilaku yang dipelajari. Untuk beberapa kejadian memang benar akan tetapi tidak benar untuk semua kasus. Teori Sutherland berdasarkan pada postulat bahwa kejahatan berasal dari organisasi sosial yang merupakan pertanyaan dari organisasi tersebut.

Menurut hasil wawancara dengan pelaku penelantaran selaku orang tua dari anak yang terlantar "Saya awalnya tidak mau menelantarkan dia, tapi karena saya lihat banyak tetangga yang melakukan penelentaran sama anak-anaknya, saya juga ikut melakukan hal yang sama, lagipula itu dianggap sudah biasa didaerah sini... yaa jadi menurut saya itu (menelantarkan 
anak) bukanlah suatu kejahatan atau pun kdrt, mbak."

Dari hasil wawancara yang didapatkan diatas, sesuai dengan teori differential association yaitu para pelaku melakukan kejahatan dari proses belajar pada perilaku menyimpang yang terjadi disekitarnya (faktor eksternallingkungan). Perilaku penelantaran anak ini dirasa sangat merugikan anak yang menjadi korban penelantaran dalam rumah tangga.

b. Berdasarkan Faktor SosioKultural (Sosiologi Kriminal)

Obyek utama dalam teori sosiologi kriminal adalah mempelajari hubungan antara masyarakat dengan anggotanya antara kelompok satu dengan kelompok lainnya, baik karena hubungan tempat / wilayah, suku, budaya, etnis, sepanjang hubungan itu dapat menimbulkan kejahatan. Terjadinya suatu kejahatan berhubungan dengan kemiskinan, kurangnya pendidikan, pengangguran dan faktor-faktor sosial ekonomi lainnya, pada negara berkembang pelanggaran banyak dilatarbelakangi oleh hal-hal tersebut.

Terjadinya suatu kejahatan sangatlah berhubungan dengan kemiskinan, pendidikan, pengangguran dan faktor faktor sosial ekonomi lainnya utamanya pada negara berkembang, dimana pelanggaran norma dilatarbelakangi oleh hal-hal tersebut. Di samping faktor ekonomi, faktor yang berperan dalam menyebabkan kejahatan adalah faktor pendidikan yang dapat juga bermakna ketidaktahuan dari orang yang melakukan kejahatan terhadap akibat akibat perbuatannya.

Hasil wawancara dengan orang tua yang menelantarkan anak, "Saya dulu waktu bekerja di proyek pembangunan masih bisa menyekolahkan anak sampai Sekolah Dasar kelas 1, tetapi karena saya dipecat dan jadi pengangguran terus cari kerja jadi pemulung. Terpaksa dia (anak) jadi berhenti sekolah dan ikut bantu saya mulung."

Dari data yang didapatkan dipenelitian ini, tindakan penelantaran anak umum terjadi apabila suatu masyarakat mengalami perubahan-perubahan yang besar dalam situasi ekonomi, yang semakin baik atau semakin buruk ketika ada kesenjangan besar antara teori-teori dan nilai-nilai ideologis yang umumnya diakui dan dipraktikkan kedalam kehidupan sehari-hari. Dari hasil wawancara diatas, dinyatakan bahwa Penelantaran Anak tersebut dirasa sangat merugikan pihak anak dan termasuk sebagai jenis kekerasan dalam rumah tangga.

Selain faktor-faktor diatas, ada juga beberapa faktor lain yang berpengaruh terhadap terjadinya penelantaran terhadap anak, yaitu:

a. Faktor Perceraian Orang Tua Perceraian orang tua sangat memengaruhi kehidupan sosial seorang anak. Saat perceraian terjadi, anak tinggal dengan salah satu orang 
tua atau bahkan tidak dengan keduanya. Perceraian dan kehilangan orang tua menjadi salah satu faktor resiko yang mendorong anak-anak menjadi terlantar. Ketidakmampuan orang tua menyediakan kebutuhan dasar, ditolak orang tua, salah perawatan atau kekerasan di dalam rumah, terpisah dengan orang tua, keterbatasan merawat anak menyebabkan penelantaran terhadap anak

b. Faktor Kemiskinan

Kemiskinan yang dihadapi sebuah keluarga sering kali membawa keluarga tersebut pada situasi kekecewaan yang pada gilirannya menimbulkan kekerasan dalam rumah tangga. Problematika finansial keluarga yang memprihatinkan atau kondisi keterbatasan ekonomi dapat menciptakan berbagai macam masalah, baik dalam hal pemenuhan kebutuhan sehari-hari, pendidikan, kesehatan, pembelian pakaian, pembayaran sewa rumah yang kesemuanya secara relatif dapat mempengaruhi jiwa dan tekanan yang sering kali akhirnya dilampiaskan terhadap anak-anak.

c. Faktor Lingkungan

Situasi yang miris atau cukup memprihatinkan yang dialami oleh anak-anak terlantar adalah tidak layaknya tempat untuk mereka bertumbuh dan berkembang. Situasi yang tidak kondisif dan lingkungan yang tidak aman menciptakan suasana tidak nyaman bagi anak. Pada umumnya mereka mengalami gangguan kesehatan secara fisik. Saat dalam situasi sakit, mereka tidak dapat ke dokter atau rumah sakit dan hanya dirawat oleh ibu/ ayah atau orang tua pengganti, bahkan ada diantara mereka tidak dipedulikan.

d. Faktor Pendidikan

Masalah paling sering yang dialami oleh anak terlantar adalah kecilnya kemungkinan untuk mendapatkan kesempatan dibidang pendidikan yang layak. Hal ini disebabkan karena beberapa aspek. Pertama, ketiadaan biaya. Kedua, keterbatasan waktu. Ketiga, rendahnya kemauan untuk belajar, dari hasil temuan di lapangan terlihat bahwa anak-anak terlantar atau diterlantarkan memiliki kemauan yang rendah dalam belajar. Keempat, adanya pemahaman yang salah terhadap pendidikan. Terakhir, kurangnya perhatian dari lingkungan. Situasi ini yang menjadikan pendidikan bukan hal yang penting bagi keluarga.

\section{Kajian Kriminologi Terhadap Penelantaran Anak Sebagai Jenis Kekerasan Dalam Rumah Tangga}

a. Kajian Kriminologi Terhadap Pelaku Penelantaran Anak

Dalam penelitian ini fenomena penelantaran anak yang terjadi adalah adanya perlakuan penelantaran yang dilakukan oleh orang tua terhadap anaknya. Penelantaran anak tersebut dilakukan oleh orang tua dapat berupa : penelantaran fisik, penelantaran 
fasilitas medis, penelantaran pendidikan, penelantaran emosi (kasih sayang), dan sebagainya. Hal tersebut merupakan suatu jenis kekerasan didalam rumah tangga dan membuat anak mendapatkan dampak yang buruk.

Dalam dunia pengasuhan anak, mereka para orang tua menyadari bahwa dengan tidak dapat memenuhi kebutuhan anak secara fisik maupun psikis merupakan tindakan penelantaran anak. Proses penelantaran anak diatas dimasukkan kedalam teori Differential Association yang membahas tentang kriminologi. Sebelum teori Differential Association diajukan oleh E. Sutherland, pergaulan sudah ditunjukkan sebagai faktor yang dapat menimbulkan kejahatan atau perbuatan menyimpang. Teori ini berdasarkan pada proses belajar, yang dimaksud dalam proses belajar ini adalah mempelajari dan memahami nilai serta norma-norma yang menyimpang oleh seseorang dari orang lain atau suatu kelompok. Menurut E. Sutherland perilaku menyimpang dipelajari didalam lingkungan sosial (eksternal), artinya semua tingkah laku kriminal atau menyimpang dapat dipelajari dengan berbagai cara.

Dalam menjelaskan proses terjadinya perilaku kejahatan, dalam penelitian ini hanya menggunakan 3 proposisi saja yang berkaitan terhadap pelaku penelantaran anak menurut teori differential association, yaitu sebagai berikut :

1) Perilaku kejahatan adalah perilaku yang dipelajari secara negatif, ini berarti perilaku kejahatan tidak diwarisi.

Menurut hasil wawancara dengan pelaku penelantaran selaku orang tua dari anak yang terlantar "Saya awalnya tidak mau menelantarkan dia, tapi karena saya lihat banyak tetangga yang melakukan penelentaran sama anak-anaknya, saya juga ikut melakukan hal yang sama, lagipula itu dianggap sudah biasa didaerah sini... yaa jadi menurut saya itu (menelantarkan anak) bukanlah suatu kejahatan atau pun kdrt, mbak."

Pada poin pertama dijelaskan perilaku kejahatan tidak diwarisi, dalam perilaku penelantaran anak ini dianggap sudah merupakan hal yang biasa dan membudaya di kalangan masyarakat (keluarga) yang tidak mampu secara ekonomi. Tindak penelantaran anak yang dilakukan orang tua merupakan suatu bentuk tindak kejahatan yang dipelajari dari lingkungan sosial (faktor eksternal) karena tinggal di tempat perumahan kumuh dan masyarakat sekitar yang juga melakukan penelantaran anak.

2) Apabila perilaku kejahatan dipelajari, maka yang dipelajari tersebut meliputi: (a) teknik melakukan kejahatan; (b) arah, motif, dorongan, alasan pembenar dan sikap-sikap. 
Menurut pengakuan salah satu orang tua anak, "Yaa mbak, saya menyadari telah melakukan penelantaran anak itu karena keterbatasan saya jadi tidak bisa menyekolahkan anak dan membelikan pakaian yang layak untuk anak saya.”

Dari poin kedua dijelaskan praktek penelantaran anak yang dilakukan oleh orang tua kepada anaknya dapat berupa penelantaran medis, penelantaran fisik, penelantaran emosi (kasih sayang) dan lain sebagainya. Sementara dorongan atau motivasi dalam melakukan penelantaran anak karena keterbatasan dalam segi ekonomi dan sebagainya.

3) Seseorang menjadi delinkuen disebabkan pemahaman terhadap definisi yang mendukung pelanggaran hukum dibandingkan dengan definisi yang tidak mendukung pelanggaran hukum.

Menurut hasil wawancara dengan orang tua yang menelantarkan anaknya "Yaa mbak, saya memang sering menyuruh anak saya untuk ngamen dijalanan, tapi yaa mau gimana lagi karena terpaksa oleh keadaan dan hasil yang didapat juga lumayan, bisa bantu sedikit untuk keperluan sehari-hari.”

Dari poin ketiga dijelaskan bahwa pelaku penelantaran anak beranggapan bahwa perbuatan menyimpang yang ia lakukan lebih menguntungkan daripada tidak melakukannya, maka ia akan memilih untuk melakukan tidakan penelantaran anak tersebut. Alasannya bias berupa lemahnya ikatan dalam keluarga antara orang tua dengan anak dan menguntungkan secara ekonomi. Dengan keuntungan yang demikian, maka pelaku akan lebih memilih untuk melanggar norma (melakukan kejahatan / perilaku menyimpang).

b. Kajian Penelantaran Anak sebagai Jenis Kekerasan Dalam Rumah Tangga

Penelantaran mempunyai pengertian yaitu merupakan kegagalan orang tua untuk memberikan keperluan hidup yang mendasar kepada anak seperti makan, pakaian, tempat berlindung, perhatian atau pengawasan kesehatan sehingga mengakibatkan kesehatan dan perkembangan anak dapat atau mungkin dapat terancam.

Penelantaran Anak merupakan suatu perbuatan yang melanggar norma hukum yang berlaku dan perbuatan ini dilakukan oleh orang tua dari anak tersebut, dimungkinkan karena orang tua tersebut tidak bisa memenuhi kebutuhan anak secara wajar, baik fisik, mental, spiritual maupun sosial. Anak-anak harus mempunyai kesempatan yang leluasa untuk bermain dan berekreasi yang harus diarahkan untuk tujuan pendidikan, dan masyarakat serta penguasa yang berwenang harus berusaha meningkatkan pelaksanaan hak tersebut

Walaupun ada seperangkat peraturan perundang-undangan yang 
melindungi hak-hak anak, tetapi kualitas permasalahannya dan tahun ketahun mengalami perkembangan kompleksitas bahaya bagi pertumbuhan dan perkembangan fisik, mental, moral, sosial dan intelektual anak.

Menurut pengakuan salah satu orang tua anak, "Yaa mbak, saya menyadari telah melakukan penelantaran anak itu karena keterbatasan yang saya punya. Saya juga memang sering menyuruh anak untuk ngamen dijalanan, tapi yaa mau gimana lagi karena terpaksa oleh keadaan dan hasil yang didapat juga lumayan, bisa bantu sedikit untuk keperluan sehari-hari."

Permasalahan kasus penelanataran anak yang terjadi marak di Negara Indonesia ini dilakukan oleh orang tua kandung mereka sendiri. Kasus penelantaran yang dilakukan oleh orang tua kandung terhadap anaknya ini jika dilihat dari sisi hukumnya merupakan perbuatan yang termasuk kedalam tindak pidana, karena jelas orang tua korban menelantarkan anak, dan ini merupakan suatu perbuatan yang dikategorikan sebagai perbuatan tindak pidana yaitu kekerasan sesuai dengan peraturan perundang-undangan yang mengatur tentang perlindungan anak yaitu Undang-Undang No.35 Tahun 2014 dan juga terdapat dalam KUHP, dijelaskan tentang ancaman hukuman pidana penjara dan denda.

Kekerasan dapat terjadi dimana saja tidak terkecuali didalam rumah tangga. Kekerasan dalam rumah tangga menurut Undang-Undang Nomor 23 Tahun 2004 tentang Penghapusan Kekerasan Dalam Rumah Tangga. Ada banyak jenis dalam kekerasan rumah tangga yaitu kekerasan fisik, kekerasan psikis, kekerasan seksual, dan penelantaran rumah tangga. Penelantaran Anak merupakan suatu perbuatan yang melanggar norma hukum yang berlaku dan perbuatan ini dilakukan oleh orang tua dari anak tersebut, dimungkinkan karena orang tua tersebut tidak bisa memenuhi kebutuhan anak secara wajar, baik fisik, mental, spiritual maupun sosial. Penelantaran anak yang dilakukan oleh orang tuanya temasuk dalam jenis kekerasan dalam rumah tangga yang sesuai menurut UndangUndang Nomor 23 Tahun 2004 tentang Penghapusan Kekerasan Dalam Rumah Tangga pada pasal 9 ayat 1 .

\section{SIMPULAN}

Berdasarkan hasil dari penelitian, maka didapatkan kesimpulan sebagai berikut :

Faktor-faktor yang menyebabkan terjadinya Penelantaran terhadap Anak didalam Rumah Tangga

Faktor faktor yang dijelaskan menggunakan Teori Kriminologi meliputi teori differential association dan teori sosio-kultural (sosiologi kriminal).

a. Teori Differential Association 
Sebab terjadinya penelantaran terhadap anak dalam penelitian ini karena adanya suatu bentuk tindak kejahatan yang dipelajari dari lingkungan sosial (faktor eksternal) oleh orang tua karena tinggal di tempat perumahan kumuh dan masyarakat sekitar yang juga melakukan penelantaran anak.

b. Teori Sosio-Kultural (Sosiologi Kriminal)

Dari hasil pembahasan didapatkan sebab terjadinya suatu kejahatan sangatlah berhubungan dengan kemiskinan, pendidikan, pengangguran dan faktor faktor sosial ekonomi lainnya utamanya pada negara berkembang, dimana pelanggaran norma dilatarbelakangi oleh hal-hal tersebut.

Faktor-faktor lain yang berkaitan dengan penelantaran terhadap anak, antara lain:

1. Faktor Perceraian Orang Tua

Faktor dari segi keluarga yaitu perceraian orang tua dan kehilangan orang tua, adapula ketidakmampuan orang tua menyediakan kebutuhan dasar, ditolak orang tua, salah perawatan atau kekerasan di dalam rumah, terpisah dengan orang tua, keterbatasan merawat anak oleh orang tua.

2. Faktor Kemiskinan

Faktor dari segi ekonomi yaitu kemiskinan yang dihadapi sebuah keluarga atau kondisi keterbatasan ekonomi yang dapat menciptakan berbagai macam masalah, baik dalam hal pemenuhan kebutuhan sehari- hari, pendidikan, kesehatan, pembelian pakaian, pembayaran sewa rumah yang kesemuanya secara relatif dapat mempengaruhi tumbuh dan berkembang pada anak.

3. Faktor Lingkungan

Faktor dari segi lingkungan yaitu keadaan lingkungan rumah yang tidak sesuai dengan standar kesehatan. Tidak layaknya tempat untuk anak bertumbuh dan berkembang menjadi penyebab timbulnya berbagai penyakit.

4. Faktor Pendidikan

Faktor dari segi pendidikan yaitu kecilnya kemungkinan untuk mendapatkan kesempatan dibidang pendidikan yang layak. Hal ini disebabkan karena beberapa aspek. Pertama, karena ketiadaan biaya. Kedua, karena keterbatasan waktu. Ketiga, rendahnya kemauan untuk belajar. Keempat, adanya pemahaman yang salah terhadap pendidikan. Dan kelima, kurangnya perhatian dari lingkungan.

Kajian Kriminologi terhadap Penelantaran Anak sebagai Jenis Kekerasan Dalam Rumah Tangga Kajian Kriminologi Terhadap Pelaku Penelantaran Anak

Fenomena terjadinya penelantaran anak di zaman modern secara kriminologis menyatakan adanya perilaku yang bertentangan terhadap norma, dan moral yang dapat dijelaskan dalam teori Differential Association yang dilakukan dalam proses belajar tentang motif, cara dan alasan pembenar. 
Kajian Penelantaran Anak Sebagai Jenis Kekerasan Dalam Rumah Tangga

Penelantaran Anak merupakan suatu perbuatan yang melanggar norma hukum yang berlaku dan perbuatan ini dilakukan oleh orang tua dari anak tersebut, dimungkinkan karena orang tua tersebut tidak bisa memenuhi kebutuhan anak secara wajar, baik fisik, mental, spiritual maupun sosial.

Permasalahan penelantaran terhadap anak yang dilakukan oleh orang tua kandung terhadap anaknya ini jika dilihat dari sisi hukumnya merupakan perbuatan yang termasuk kedalam tindak pidana, karena jelas orang tua menelantarkan anak, dan ini merupakan suatu perbuatan yang dikategorikan sebagai perbuatan tindak pidana yaitu kekerasan dalam rumah tangga sesuai dengan peraturan perundang-undangan yang mengatur tentang Perlindungan Anak yaitu Undang-Undang No.35 Tahun 2014 dan juga terdapat dalam Undang-Undang Nomor 23 Tahun 2004 tentang Penghapusan Kekerasan Dalam Rumah Tangga maupun didalam KUHP, dijelaskan tentang ancaman hukuman pidana penjara dan denda.

\section{SARAN}

Berdasarkan hasil penelitian, maka dapat diberikan saran sebagai berikut : Perlunya dilakukan tindakan tegas oleh pemerintah terhadap pelaku penelantaran anak karena mengingat penelantaran anak merupakan suatu tindak kekerasan dalam rumah tangga dan perilaku tersebut bertentangan terhadap norma dan moral.

Untuk mencegah banyaknya penelantaran terhadap anak yang disebabkan oleh faktor perceraian orang tua, maka pemerintah maupun lembaga masyarakat diharapkan dapat memberi penyuluhan, pendampingan psikologis terhadap keluarga yang bercerai sehingga anak sebisa mungkin tidak merasakan kehilangan kasih sayang dari salah satu ataupun kedua orang tuanya penelantaran anak terhadap masyarakat agar menghindari adanya penelantaran anak.

Untuk mencegah banyaknya penelantaran terhadap anak yang disebabkan oleh faktor kemiskinan, maka pemerintah diharapkan dapat mengurangi kemiskinan yang ada di Indonesia.

Untuk mencegah banyaknya penelantaran terhadap anak yang disebabkan oleh faktor lingkungan, maka pemerintah maupun lembaga masyarakat diharapkan dapat memberi penyuluhan tentang lingkungan rumah yang sehat dan perlunya tempat tinggal yang layak dan aman untuk anak agar penelantaran terhadap anak dapat dihindari.

Untuk mencegah banyaknya penelantaran terhadap anak yang disebabkan oleh faktor pendidikan, maka pemerintah maupun lembaga 
masyarakat diharapkan dapat memberi penyuluhan tehadap orang tua agar mereka memahami tentang pentingnya pendidikan pada anak untuk masa depan yang baik untuk anak mereka.

\section{DAFTAR PUSTAKA}

Buku :

Abdussalam, 2007, Kriminologi, Restu Agung, Jakarta.

Alam, A.S., 2010, Pengantar Kriminologi, Pustaka Refleksi, Makassar.

Arikunto, Suharsimi, 1998, Prosedur Penelitian Suatu Pendekatan Praktik, PT. Rineka Cipta, Yogyakarta.

Bintania, Aris, 2008, Hukum Islam Vol VIII No.2.

Darwan Prints, 2002, Hukum Anak Indonesia, PT. Citra Aditya Bhakti, Bandung.

Darma Weda, Made, 1996, Kriminologi, PT. Raja Grafindo Persada, Jakarta.

Effendi, Tolib, 2017, Dasar - Dasar Kriminologi, Setara Press, Malang.

Hadisuprapto, Paulus, 2008, Delikuensi Anak Pemahaman dan Penanggulangannya, Bayumedia Publishing, Malang.

Hasan Wadang, Maulana, 2003, Advokasi dan Hukum Pelindungan Anak, Gramedia Widiasarana, Jakarta.

Kamus Besar Bahasa Indonesia, 1990, Balai Pustaka, Jakarta.
Kemal Dermawan, Mohammad, 1994, Strategi Pencegahan Kejahatan, PT. Citra Aditya Bakti, Bandung.

Meier, Robert F, 1989, Crime and Society, Allyn and Bacon, Massachusetts.

Mulyadi, Lilik, 2005, Pengadilan Anak di Indonesia ( Teori Praktek dan Permasalahannya), CV. Mandar Maju, Bandung.

Narbuko \& Abu Achmadi, Cholid, 2001, Metodologi Penelitian, Bumi Aksara, Jakarta.

Setyowati, Irma, 1990, Aspek Hukum Perlindungan Anak, Bumi Aksara, Jakarta.

Soemitro, Ronny Hanitijo, 1998, Metodologi penelitian hukum dan Jurimetri, Ghalia Indonesia, Jakarta.

Soeroso, Moerti Hadiati, 2010, Kekerasan Dalam Rumah Tangga Dalam Perspektif Yuridis Viktimologis, Sinar Grafika, Jakarta.

Salim, H.S, 2005, Pengantar Hukum Perdata Tertulis, Sinar Grafika, Jakarta.

Susanto, Is, 2011, Kriminologi, Genta Publishing, Jakarta.

Sutherland, Edwin H., 1973, Azas Azas Kriminologi, Alumni, Bandung.

Waluyadi, 2009, Hukum Perlindungan Anak, CV. Mandar Maju, Bandung. 
Peraturan Perundang-Undangan:

Undang - Undang Dasar tahun 1945

Undang - Undang Nomor 1 tahun 1974 tentang Perkawinan

Undang - Undang Nomor 35 tahun 2014 tentang Perubahan atas Undang-Undang No.23 tahun 2002 tentang Perlindungan Anak.

Undang - Undang Nomor 23 tahun 2004 tentang Penghapusan Kekerasan Dalam Rumah Tangga.

Undang - Undang Nomor 39 tahun 1999 tentang Hak Asasi Manusia.

Undang - Undang Nomor 3 tahun 1979 tentang Pengadilan Anak.

Undang - Undang Nomor 4 tahun 1979 Tentang Kesejahteraan Anak.

\section{Sumber Lain:}

Departemen Sosial "Penelantaran

Anak"

http://yannrehsos.depsos.go.id.

Diakses pada tanggal 18 Bulan Mei 2018.

http://rotsania.blogspot.co.id/2012/11

/penelantaran-anak.html.

Diakses pada tanggal 21 Bulan Mei 2018.

https://www.idjoel.com/pengertiananak-menurut-para-ahli/. Diakses pada tanggal 10 Bulan Mei 2018.

http://id.wikipedia.org/kekerasan.

Diakses pada tanggal 20 Bulan Mei 2018. 